2008

\title{
Is the World Social Forum the Privileged Space for Reinventing Labor as a Global Social Movement?
}

Waterman

Follow this and additional works at: https://scholarlycommons.law.case.edu/swb

Part of the Human Rights Law Commons, and the Social and Behavioral Sciences Commons

\section{Recommended Citation}

Waterman. 2009. "Is the World Social Forum the Privileged Space for Reinventing Labor as a Global Social Movement?." Societies Without Borders 3 (1): 154-167.

Available at: https://scholarlycommons.law.case.edu/swb/vol3/iss1/11 


\title{
Is the World Social Forum the Privileged Space for Reinventing Labor as a Global Social Movement?
}

\author{
Peter Waterman \\ The Netherlands
}

Keywords

labor, WSF, Decent Work, unionization

The World Social Forum (WSF), represents a global pressure-cooker of contemporary progressive and emancipatory social movements and ideas. This is the case also for the international trade union and labor movements, regardless of their still somewhat marginal position within the WSF. What follows are reflections on such matters, including, eventually, the reasons for distinguishing between 'progressive' and 'emancipatory', 'unions' and 'labor' - and for the 'relative marginality' of labor and unions at the WSF.

A couple of days (daze?) into the simultaneous stimulation and confusion of the 7th World Social Forum, Nairobi, January 20-25, 2007, I had a background item on labor, written prior to the forum, published in the semi-official Forum daily, Terra Viva. ${ }^{1}$ The article suggested a tension between a dominant trade-union tendency, propagating 'Decent Work', and a marginal one that I dubbed the 'Emancipation of Labour'. ${ }^{2}$ Reading my piece, in cold print, in Nairobi, I had a flashback to the World Festival of Youth and Students, Moscow, 1957, 50 years earlier...

... these festivals were organized by the World Communist movement, of which the International Union of Students was a prominent part. Aged

\footnotetext{
1) Waterman 2007a.

2) Compare Bieler 2007. 
21, I was the English Editor of its magazine, World Student News. In Moscow I was expected to be part of the team producing the Festival's daily paper. I turned up for duty a couple of days before the Festival began and was asked to do a report on the International Student Day which was evidently - yet to occur. Questioning this Soviet journalistic practice I was informed that the slow production process did not permit us to report events after they had occurred. "But what," I asked, "if it rains?" "Don't worry, came the reassuring reply, "If it doesn't rain in the newspaper then it didn't rain”.

\section{Candidates for Categories}

Back to Nairobi: My little anxiety attack was about whether my speculative piece in Terra Viva was in danger of being rained on by reality.

It turned out that my pre-Forum assumption about the dominant role of Decent Work (DW) was borne out in the Forum. This strategy was energetically promoted, top-down, by the new International Trade Union Confederation (ITUC). DW appeared to be the pensée unique (single idea) to which all union events were subordinated, whatever or whoever they were actually about (children, women, migrants, the informal sector and trade, worker rights, etc.). Indeed, this concept or strategy was being enthusiastically endorsed and promoted even by Southern unions, by labororiented NGOs or autonomous labor movements, such as StreetNet. ${ }^{3}$

But did the Emancipation of Labour (EoL) tendency exist outside my fevered imagination? EoL proved to be scarcely trumpeted by the body that had funded my participation in the Nairobi WSF. This was the Swedish NGO, Agora/Arena, itself supporting a book project co-edited by Andreas Bieler (Germany/UK), Devan Pillay (South Africa) and Ingemar Lindberg (Sweden). The project had, actually, no political pretensions. But the book may nonetheless make an original contribution to the EoL in so far as it addresses not only the unionized or unionizable working class but also that growing proportion of the world labor force outside the 'formal sector' and therefore non-unionized or un-unionizable. My own contribution to the collection is on the implications of globalization and the global justice movement for the future of labor internationalism. ${ }^{4}$ But despite a

\footnotetext{
3) Streetnet International Report 2007.

4) Waterman $2007 \mathrm{~b}$.
} 
well-attended and often lively three-session seminar at the Forum, this research project turned out to have no common theoretical orientation or distinct strategic implications, and no clear political orientation. Or, rather, it seemed to have one foot in the Thirdworldist Marxist project of Samir Amin ${ }^{5}$ one foot in (ex-?) social-democratic Scandinavia, and toe-holds in South Africa and Nottingham, UK (ideologically unqualifiable). This may all shape up, of course, as a result of the Nairobi exchanges, or possibly of comments on the Global Working-Class Project's Nottingham website. At the moment of the WSF, however, the project seemed to be balancing, or caught, between various New Left (1968) paradigms, either explicit or implicit. Readers may judge the outcome for themselves. ${ }^{6}$

My second candidate, after the Global Working Class Project, for the EoL logo was Labour in Movement: Facing the Challenge of Globalization, an initiative coming from a group of WSF-friendly unions and unionists, and 'base' movements of unions, mostly in Western Europe. It has some connection with a network called Transform! I had been in correspondence with Marco Berlinguer, the coordinator of this initiative, for some time and had understood that this WSF effort was a primarily political one, however cautiously expressed. If, however, it is to be reasonably characterized as an EoL project, then it has to be further understood as an emancipation that began at the Nairobi WSF with a whisper rather than bang. After several rounds of informal discussion (part of it under a shade tree, symbolically sited outside the pavilion occupied by Decent Work), what appeared was a proposal for a 'WSF inspired' network and website on labor globally, startling in its modesty.

This document was then submitted to a morning workshop that was impressively well attended. My rough guess is that there were 200-250 people there - including several from the Global Working-Class Project. What this initiative amounts to is no more - or less - than its title. The modesty of this proposal, and the caution with which it is being launched upon the WSF and the wider world of work, should not be under-estimated. The proposal states:

Neoliberal globalisation implies the most vicious attack on labour in living memory. Yet labour has so far had neither the necessary centrality, nor even visibility, within the WSF process. We propose for this purpose to build a labour network on and in the

5) Bamako Appeal 2007.

6) Bieler et al. 2008 . 
WSF process. This network will link different experiences, understandings of and skills engaged in every place and every aspect of work.

Although I feel this proposal lacks bite, if this network/website does come into existence, it will not only be the first labor body to address itself to labor 'on and in the World Social Forum' it would also, I believe, be the first global network on, and of, 'labor-in-general'! There exist, of course, endless union websites, as well as many autonomous labor-support networks and websites. But, with welcome exceptions, the union websites tend to reproduce the pyramidal structure of the unions themselves, with no feedback feature, far less open discussion. And the 'alternative' labor websites, including those for solidarity on particular issues, with particular countries, or for particular categories (e.g. contingent, casual, day or precarious labor) - even on Global Labor Strategies - do not have the holistic potential of this proposal.

It may be because of the breadth and openness of the initiative that the workshop response was so positive, receiving the support of speakers, for example, from the Italian CGIL, the Quebec-based World March of Women, the South Africa-based StreetNet, the New Trade Union Initiative in India, various European 'base' organizations, the Central Única dos Trabalhadores (CUT-Brazil), the Central de los Trabajadores Argentinos (CTA Argentina), and even from officers of some of the traditional tradeunion internationals present. In any case, the proposal then went forward to a chaotic afternoon session on the 4th and last day of the forum, at which all proposals on labor were supposed to be discussed and eventually forwarded to ... the WSF-in-General?... the Closing Ceremony?... the International Council of the WSF...? Here, in a tent divided by canvas from even noisier others, with no sound equipment, with interpreters valiantly struggling to make sense of speakers behind them and facing the opposite direction, just two proposals were submitted to a largely bemused and uncomprehending audience. One was Decent Work, submitted at length, in French, by a woman unionist from Haiti. I understood only that there was going to be a three-year campaign internationally on DW. The other proposal was the Labour Network, presented in English, under the same constraints. Whilst reassured, to some extent, that reality had provided at least two candidates for my two Terra Viva categories, I was disappointed that there were only two proposals to go forward and that those that did were being forwarded under the conditions of what has to be called Chaotic and Incomprehensible Democracy. In the event, the 
Labour Network proposal, if not the Decent Work one, was forwarded further, landing in the tent of the Social Movement Assembly (2007).

Actually, I should have identified a third EoL candidate at the Forum, the Bamako Appeal of 2006 itself, since Ingemar Lindberg had apparently drafted the challenging labor chapter (actually half-page) of that 2005 project, and Samir Amin was apparently the inspiration for the global labor book itself. But Amin only turned up to briefly and vaguely bless the book project. And I missed either attendance at or verbal reports of the 10-session World Forum of Alternatives (WFA) events that were in some way the follow-up to his Bamako Appeal. The first WFA conference of this NGO was entitled (in caps):

\section{FOR THE UNITY OF THE WORKING PEOPLES \\ (WORKERS, PEASANTS, WAGE EARNERS, UNEMPLOYED, INFORMAL), RIGHTS AND ACCESS TO LAND}

My non-attendance (due to the timetable clashes inevitable when 1,200+ events occur in three days) is regrettable, since there were a number of major organizations and speakers listed, including Ingemar Lindberg. But despite the promise of this event, the WFA failed to make an appearance or take a stand at the final collective event on labor strategy. So unless and until something issues from it, the nature and purpose of the WFA labor project remains unclear. ${ }^{7}$ There may well have been other such initiatives occurring in corners of the enormous Forum site.

\section{The Meaning of Decent Work and the Emancipation of Labor}

I have elsewhere dealt at some length with Decent Work. ${ }^{8}$ Depressingly, indeed, a search suggests I am one of maybe only two or three people who has criticized it at any length. ' So a repetition may not be out of place: DW is a projection at the global level of the kind of social partnership (i.e. a junior partnership of labor with capital and state) that existed for working people in certain West European countries under National Keynesianism, around the third quarter of the last century: the model is, or was,

\footnotetext{
7) As also in Amin 2007.

8) Waterman 2005.

9) Compare Vosko 2003.
} 
Scandinavia. ${ }^{10} \mathrm{DW}$ deals with labor and social rights and conditions but raises no question about whether the work that is decent is also useful, and necessary, it raises no question about capitalist or state ownership and control, nor does it consider whether the DW strategy increases the power and autonomy of laboring people. DW, moreover, did not originate with the trade unions, with some latter-day Karl Marx, or the labor movement at all: it was thought up by Juan Somavia, Director General of the International Labour Organization (ILO), the UN's inter-state body for labor questions. Whilst no one can possibly reject the notion of improving wages, rights and conditions, neither can one assume that this global NeoKeynesian project is 1) possible, and 2) will not be eventually dumped in the same garbage bin as national Keynesianism. DW is, further, being promoted top-down by the inter/national unions concerned, without any preliminary discussion of such challenges (and many hypothetical others) by either unions, labor NGOs, labor researchers, or, of course, workers themselves. Moreover, the Decent Work coalition actually consists of the ITUC, like-minded union internationals, ${ }^{11}$ and three or four Social- or Christian-Democratic NGOs, all from the West, the majority based, like the ITUC, in Brussels (base also of major DW inter-state funder, the European Union). No one, finally, has even considered whether this new socialpartnership project is not going to reproduce the failure - after 15 years of effort - of its forerunner, the 'Social Clause' campaign. This was intended to lobby international labor rights out of the World Trade Organization (WTO) and its predecessor - bodies that were destroying them. It has been quietly buried: no funeral, no flowers, no obituary... no accounting of costs. ${ }^{12}$

As for the Emancipation of Labour, this is a rather more problematic concept since it began in my mind simply as a provocative slogan. True, it is inspired by the early labor movement, at a time when this was intimately related with democratic, international solidarity and national independence movements, and often led such. The word 'emancipation' is older and wider than the historical labor movement, having been used, of course, by the movement against slavery, by the women's and other such movements. Applied to labor, 'emancipation' reminds us of that historical tradition that considered wage-labor as wage-slavery - something to be liberated

\footnotetext{
10) For the decline, see Bieler and Lindberg 2007; International Union Rights 2007.

11) ETUC 2007.

12) Waterman 2001.
} 
from. As with the women's movement, 'emancipation' could suggest to labor the necessity for collective self-activity against alienation: in this case the alienation of human productive and creative capacities to the benefit of capital and state (not to speak of patriarchy, imperialism, consumerism, racism, competitive individualism and ecological destruction). 'Emancipation', for me, also has to do with self-transformation, with the reinvention of one's own behaviors and identity, and from the ineffective means by which one has previously expressed oneself collectively. Which is what I have been concerned with when writing on the 'emancipation of labor internationalism'. ${ }^{13}$

\section{Progressive or Radical?}

Another reason for caution about the epithet EoL is uncertainty about how Labour in Movement (or anything from either the World Forum of Alternatives or the Global Working Class project) will be seriously radical rather than generally progressive. My feeling is that the emancipation of labor, or even its effective defence, requires subversion of the dominant ideology, the use or invention of new language, new ways of doing things, and forceful assertion. It eschews diplomacy, which is, after all, a code of behaviour for international elites (it means shaking hands so that the daggers fall out on the floor before discussions begin). Emancipation is not simply a new policy or strategy - which many around the Forum are certainly advancing - but a new ethic or culture. For myself, 'emancipation' implies not simply a leadership or policy challenge to those who have hegemony within the international labor movement, but the creation of a new culture, ethic, modes of relating to workers, union members, other union leaders - and 'labour's others' - that vast majority of the world's working people beyond the reach of unions. ${ }^{14}$

Now, there is actually no binary, far less a Manichean, opposition between the two labor tendencies I identify above. StreetNet, for example, identified itself with both in Nairobi. Moreover, I think that Decent Work has to be recognized as a step forward from the pathetic Social Clause lobbying campaign, and as representing an assertion where years of 'concession bargaining' and state-dependent protectionism represented retreat. It

\footnotetext{
13) Waterman 2004a.

14) Jha 2007; Waterman 2007c.
} 
appears, further, from Nairobi as if DW was to be a matter of union campaigning, thus engaging rank-and-file unionists, who might then question what kind of pig there is in this poke. And, on the other hand, the emancipatory - or at least innovatory and adventurous - tendency I have identified, is itself an unknown quantity. Bearing in mind, moreover, the monolithic nature and hegemonic claims of the Decent Work project, it does seem to me that its origins, its assumptions, its implications simply have to be subject to open discussion, and then within several concentric agoras, the crucial one being the most distant and difficult: that of workers themselves, where they work and live (as Nairobi demonstrated, most working people outside the capitalist core may be more concerned with their rights as inhabitants than their rights as workers). ${ }^{15}$

\section{The Privileged Place/Space for Dialogue on Labor Globally?}

The privileged place and/or space, for dialogue on the re-invention of a global labor movement under contemporary conditions, may at present be the World Social Forum and the wider Global Justice and Solidarity Movement (GJ\&SM). I mention the second of these entities, however problematic it might appear, because we must remember where the WSF comes from, where it is situated and that many union organizations and other labor movements are active within the latter, even when they might not be present in the former. The privilege I accord the WSF is due to the principles underlying its formation. These could be traced back to an ecumenical document of the 1980s, attached to the latest defense of the 'Forum-as-Space' by Forum founder, Chico Whitaker. Arguing the necessity for 'intercommunication' in emancipatory struggle, this document lists its necessary characteristics: freedom of expression, liberty of information, equality of opportunity, mutual respect and openness toward the others, mutual confidence, active co-responsibility, acceptance of heterogeneity and of the dynamic of conflicts that go with it. The aim is to transform 'domination power' into 'service power'. The latter implies:

First of all, the exercise of the power each of us disposes in terms of COUNTERPOWER, that which aims to neutralize the power of the dominated over the resources that they dispose of as the stopping of a factory or the denouncing of a lie. In the second place, the exercise of an ALTERNATIVE POWER, which aims to eliminate

15) Oloo 2006a. 
our dependence on the dominating when for example we discover the ways to satisfy a given need without using resources owned and controlled by the dominating. ${ }^{16}$

I would consider such principles to be represented and promoted, if not hegemonic, within the WSF and the broader GJ\&SM. They are also a matter of self-reflection within and around such. ${ }^{17}$

The reason why I here say that a new way of being, thinking and acting is not hegemonic within the Forum is revealed by the relationship between the inter/national trade union organizations and the WSF in the period leading up to Nairobi. What is publicly known is that there was tension between the Kenyan Confederation of Trade Unions (COTU) and the organizing committee, with COTU initially complaining of exclusion but later reporting a settlement and, indeed, a certain satisfaction with the Nairobi WSF. The tension was at least in part due to the international unions' desire to get all WSF activities under the banner of Decent Work. There was resistance by members of the International Committee to having this inter-state organization policy (issuing from the ILO) stand in place of 'Labour' in the official program. ${ }^{18}$ According to one account, the union side (local? regional? international?) threatened a boycott of the Nairobi WSF if the ILO/ITUC language was not used. And the relevant committee felt it had to back down in the face of the threat.

All this politicking explains why in some parts of the published WSF program the word 'labor' is used and in other parts 'decent work' (uncapitalized?). It seems, in any case, as if a certain amount of dirty work was involved in the advancing of Decent Work. The labor question in Nairobi was thus surrounded by clouds of complicity and compromise that made it difficult to see any little swords of justice around.

Petty and insignificant as this affair might seem in the light of what publicly - and promisingly - occurred in Nairobi, it surely still requires public clarification. Because, if that kind of pressure was exercised, and if the WSF did feel obliged to quietly concede, then this surely exemplifies the old way of doing (labor or left) politics. And this is surely in contradiction with the necessary new ethic as variously expressed above by Chico Whitaker (from Liberation Theology in the 1980s), Ezequiel Adamovsky (from the 21st century autonomists, 2006) ... or myself, from Moscow, 1957.

\footnotetext{
16) Whitaker 2007, p. 239.

17) Wainright et al. 2007.

18) Oloo 2006a.
} 
If I still argue that the WSF is a privileged place for the reinvention of the international labor movement, then how do I explain the latter's relatively low profile? So far, it seems to me, the WSF and the trade union organizations have had an instrumental rather than an affective relationship. This means that each has used the other for its own predetermined purposes - the ITUC most recently for promoting Decent Work, the WSF for demonstrating its inclusion of what is, after all, the major organized body of the popular classes globally. The unions have, traditionally, run a full program in their own WSF space, but this is one which simultaneously concentrates and isolates. Thus, despite formal ITUC urgings that unionists participate in other events, this is more likely to be on group or individual initiative of the unionists ${ }^{19}$ than anything more structural, effective and visible.

Now, many feminists continue to complain of the low profile or even marginalization of women within the WSF. This is not my impression, either from their autonomous activity in preparation for the Forum (Feminist Dialogues), or their activity in its International Council, or their presence in public Forum events and its open spaces. ${ }^{20}$ I would argue that the higher profile of women compared with labor has been a result of the determined activity of feminists and women's networks, recognizing their affinity with the Forum but systematically pressing their issues within and upon it. There has also been much more reflection on the Forum from the women's movement than from the labor one. The reasons are not far to find. The trade unions and even the broader labor and socialist movement are children of early/mature capitalism. The women's movement and feminism are, in their present incarnation, the children of mature or late (I adhere to the 'principle of hope') capitalism. They were, indeed, a major force in the New Social Movements of the 1970s-80s. Without them one cannot understand the nature of the WSF and the Global Justice and Solidarity Movement. Thus, we see a leading male organizer publicly reflecting on the position of women within the Forum, ${ }^{21}$ but we do not yet see middle-class Forum organizers (men or women) seriously reflecting on the role of labor there.

\footnotetext{
19) Bonin 2007; de Schryver 2007a, b.

20) Vargas 2007.

21) Oloo 2006b.
} 


\section{Post-Nairobi Update: Reality Bites ${ }^{22}$}

After nine months gestation, the baby of an emancipatory labor internationalism is still refusing to be born. Having myself been involved in three different international labor events (or labor events internationally), and having received reports from a fourth, it gives me no pleasure to say this. But, as would-be midwife, I still have a duty of explanation.

I think the problem is that the union left internationally is still 1) a prisoner of the union form as we have known it since 1945,2) limited by capitalism's notion of work, as that which is done for wages in a large-scale industrial or clerical enterprise (capitalist or state), 3) disoriented by the violent assault of neo-liberal globalization and the collapse of Communist, Social Democratic or Radical-Nationalist utopias. As a result of one or more of the above it is unable to pose or even imagine a post-capitalist alternative. Given the increasing ambiguities of the World Social Forum's 'other possible world', even a union embrace of the WSF would not necessarily challenge the ILO/ITUC Decent Work hegemony. Far less would it be likely to stimulate an autonomous international movement for the liberation of life from work. Major Southern unions and the ITUC itself have recently submitted themselves as candidates to the WSF's crucial new 'Liasion Committee' - meant to keep the operation running between meetings of the massive and unwieldy International Committee. These candidatures are unlikely to be evaluated according to their opposition to a social partnership with capital, national or international.

So from where are we to draw, on what ground are we to base, any optimism of the will? And where is a labor alternative most likely to be able to shape itself? Well, signs and sounds of autonomous and emancipatory labor movements and thinking are still to be found here, there and everywhere. Last year we saw the greatest ever Mayday ever in the USA - and it was of illegal immigrant workers! National and regional labor support and solidarity networks in East Asia quietly but vigorously address the urgent needs of new working classes of China and Asia, unionized or not. The Korean Confederation of Trade Unions is making the most serious self-criticism and carrying out the most energetic search for an alternative strategy addressed to all working people in South Korea. ${ }^{23}$ Word has it

\footnotetext{
22) Some of what I mention below may be detailed in Waterman 2007a-d. Others, in this changing situation, are hearsay and will have to be confirmed later.

23) Yang Kyung-kyu 2007.
} 
that an international union-plus-social-movement seminar on 'A Fair Globalisation' in Lima, Peru, September, 2007, actually heard radical positions and ended with a singing of 'The Internationale'! Recent books, magazines and websites suggest a rise in radical-democratic thinking, and a desire for international dialogue, that has not existed since the 1970s. However, I am wondering whether we will not have to wait for some equivalent of the Zapatista uprising of 1994, or the Burmese uprising of 2007 , to shake international labor out of a caution - if not an inertia - that presently paralyses it.

And I am also convinced that any emancipatory labor internationalism is going to need a virtual platform or agora if it is to have any international profile or force. And that that profile and force will need to express themselves also beyond the WSF, within the rather wider and deeper space represented by a global justice and solidarity movement that is still in formation.

\section{Acknowledgements}

Thanks to the following for feedback on previous drafts or related writings. Dan Gallin, François Houtart, Paul Garver, Andreas Bieler, Marco Berlinguer, Ingemar Lindberg, Mac Urata and others. The usual disclaimer applies.

\section{References}

Adamovsky, Ezequiel 2006, 'Autonomous Politics and its Problems: Thinking the Passage from Social to Political', http://info.interactivist.net/article.pl?sid=06/05/25/225244 \&mode=thread \& tid $=9$.

Amin, Samir 2007, 'Le Forum Social Mondial est-il utile pour les luttes populaires ? Les formules des forums sociaux le sont-elles?' [Is the World Social Forum Useful for Popular Struggles? Are the Social Forum Formulas Such?], http://www.nadir.org/ nadir/initiativ/agp/free/wsf/nairobi2007/0201le_forum_social_mondial.html.

Bamako Appeal 2007, 'The Bamako Appeal', in Jai Sen and Madhuresh Kumar (eds.), $A$ Political Programme for the World Social Forum? Democracy, Substance and Debate in the Bamako Appeal and the Global Justice Movements: A Reader, pp. 151-176, New Delhi: CACIM and Durban: Centre for Civil Society.

Bieler, Andreas and Ingemar Lindberg 2007, 'Swedish Unions and Globalisation: Labour Strategies in a Changing Global Order', Global Working Class Project, http://www. nottingham.ac.uk/politics/gwcproject/index.php.

Bieler, Andreas, Ingemar Lindberg, and Devan Pillay 2008, Labour and the Challenges of Globalisation: What Prospects for Transnational Solidarity?, London: Pluto. 
Bonin, Marie-Hélène 2007 'World Social Forum: Stronger Alliance of Unions with Social Movements', http://www.alternatives.ca/article2784.html?lang=en.

CACIM (India Institute for Critical Action: Centre In Movement), http://cacim.net/twiki/ tiki-index.php?page=CACIMHome

Choike, 'About the World Social Forum', http://www.choike, org/nuevo_eng/informes/ 4601.html

Decent Work, Decent Life, http://www.ituc-csi.org/spip.php?rubrique69.

De Schryver, Marc-Antoon 2007a. 'De Belgen op het WSF (1): Luc Hamelinck van het ACV', 260107, http:www.indymedia.be/nl/node/6885.

De Schryver, Marc-Antoon 2007b, 'De Belgen op het WSF (2): Eddy van Lacker en Caroline Copers van het ABVV', 280107. http: www.indymedia.be/nl/node/6919.

E-Library for Social Transformation, http://www.openelibrary.info/main.php.

International Union Rights 2007, 'Focus on Labour Rights in the Nordic Countries and Baltic Region', International Union Rights, 13: 2-23.

Feminist Dialogues, http://feministdialogues.isiswomen.org/.

Global Labor Strategies, http://laborstrategies.blogs.com/.

Global Working Class Project, http://www.nottingham.ac.uk/politics/gwcproject/index.php.

International Trade Union Confederation, www.ituc-csi.org/New Unionism, http://www. newunionism.net/.

Jha, Praveen 2007, 'Globalisation and Labour in India: The Emerging Challenges'. Global Working Class Project, http://www.nottingham.ac.uk/politics/gwcproject/index.php.

Oloo, Onyango 2006a, 'Social Movements Set to Assert Their Presence at WSF Nairobi 2007', http://www.pambazuka.org/en/category/comment/38952.

Oloo, Onyango 2006b, 'Gendering the WSF Nairobi 2007 Process: A Contribution to a Debate by Onyango Oloo, National Coordinator, Kenya', www.nigd.org/nigd/nigdwsf-area/wsf-material/WSFArticles.

Reese, Ellen, Erika Gutierrez, and Christopher Chase-Dunn 2007, 'Labour and Other Antisystemic Movements in the World Social Forum Process', Department of Sociology, University of California-Riverside, http://irows.ucr.edu/papers/irows17/ irows 17.htm.

Sen, Jai and Madhuresh Kumar (eds.) 2007, A Political Programme for the World Social Forum? Democracy, Substance and Debate in the Bamako Appeal and the Global Justice Movements: A Reader, New Delhi: CACIM and Durban: Centre for Civil Society.

Social Movement Assembly 2007, 'Full Report of The Social Movements Assembly: World Social Forum, Nairobi, 16h-18h, 24 January 2007', http://www.focusweb.org/fullreport-of-the-social-movements-assembly.html.

Streetnet International Report 2007, 'Streetnet International Report on the World Social Forum (WSF2007), Nairobi, Kenya, 20-25 January 2007'.

Transform! European Network for Alternative Thinking and Political Dialogue, http:// www.transform-network.org/index.php?id=395.

Union Ideas Network, http://www.uin.org.uk/.

Vargas, Virginia, 'Una mirada al FSM de Nairobi' [A view of the Nairobi WSF], e-mail received 16-02-07.

Vosko, Leah 2003, 'Decent Work', The Shifting Role of the ILO and the Struggle for Global Social Justice', in Marjorie Griffin Cohen and Stephen McBride (eds.), Global 
Turbulence: Social Activists' and State Responses to Globalisation, pp. 174-190, Aldershot: Ashgate.

Wainright, Hilary et al. 2007, Networked Politics: Rethinking Political Organisation in an Age of Movements and Networks, Amsterdam: Transational Institute.

Waterman, Peter (ed.) 2001, 'Labour Rights in the Global Economy', Working USA (guestedited special issue), 5: 9-86.

Waterman, Peter 2005, 'From "Decent Work" to "The Liberation of Time from Work": Reflections on Work, Emancipation, Utopia and the Global Justice and Solidarity Movement', http://info.interactivist.net/article.pl?sid=05/03/24/170247\&mode=nested\&tid=4.

Waterman, Peter 2007a, 'Trade Unions, Labour and the World Social Forum', Terra Viva, January 2, http://www.ipsterraviva.net/tv/Nairobi/en/viewstory.asp?idnews=777.

Waterman, Peter 2007b, 'Trade Union Internationalism and the Challenge of Globalisation: The Beginning of the End or the End of the Beginning?', Global Working Class Project. http://www.nottingham.ac.uk/politics/ gwcproject/ index. php.

Waterman, Peter 2007c, 'The Networked Internationalism of Labour's Others: A Suitable Case for Research', Conference of the International Association of Labour History Institutions, Linz, Austria, 13-15 September 2007.

Waterman, Peter 2007d, 'International Labour Studies (UK) in the Light of Social Justice and Solidarity (Globally)', http://www.openspaceforum.net/twiki/tiki-read_article. php?articleId $=440$.

Whitaker, Chico 2007, 'Annex 12: For an Evaluation of the International Study Days Project: Why It Is Necessary to Continue It?', in A New Way of Changing the World, pp. 225-246, Nairobi: All Africa Conference of Churches.

Yang Kyung-kyu 2007, 'The Crisis and New Challenges of the Korean Labour Movement', Notes of Presentation to 30th Anniversary Conference of the Asia Monitor Resource Centre, Hong Kong, Asian Labour Update (Hong Kong). 
Copyright of Societies Without Borders is the property of Brill Academic Publishers and its content may not be copied or emailed to multiple sites or posted to a listserv without the copyright holder's express written permission. However, users may print, download, or email articles for individual use. 